\title{
MODEL OF CORPORATE GOVERNANCE OF A MODERN ENTERPRISE IN THE 21ST CENTURY
}

\author{
Zorica Siljanovska, PhD \\ FON University, Faculty of Law, Skopje, Macedonia \\ zorica.siljanovska@fon.edu.mk \\ Mirjana Matovska, PhD \\ FON University, Faculty of Economics, Skopje, Macedonia \\ Elena Karovska, m-r \\ FON University, Faculty of Law, Skopje, Macedonia
}

\section{Professional Paper doi:10.5937/jouproman5-12980}

\begin{abstract}
Efficient and quality system of corporate governance built on high set international standards and principles allows setting goals that are consistent with the interests of all stakeholders.

The definition of corporate governance made by the OECD, which today is one of the most widely accepted and comprehensive definition confirms the importance of all constituents and care for their interests when setting objectives. Quality corporate governance is reflected in the mechanisms that establish a balance between the different interests of stakeholders.

Each constituency is part of the mosaic should not be marginalized and ignored.
\end{abstract}

Keywords: company, corporate governance, international standards stakeholders.

\section{Introduction}

\section{Berle - Means model of corporate governance}

Berle - Means model of corporate governance dates back to 1932. It was created by prominent experts Adolf Berle ${ }^{1}$ and Gardiner Means ${ }^{2}$, in which bears his name, was first published in their book

\footnotetext{
1 Adolf Berle, was born in Boston, 1895-1971, lawyer, educator, author and American diplomat. He was a prominent member of the team of US President Franklin Roosevelt, with his ideas and work Modern privately owned company and had a huge contribution to the development and improvement of corporate governance.

${ }^{2}$ Gardiner Means, 1896-1988, American economist who worked at Harvard University. Co-author of the work and Modern privately owned company, was a major contribution to the development of corporate governance with its revolutionary ideas in 1962 published work Corporate revolution in America.
}

The Modern Corporation and Private Property ${ }^{3}$. Second revised edition of the book of the same name is published in 1967. This model resembles many features of today's model of corporate governance of companies and rightly findings of many analysts that Berle Means model is a reality after 75 years of its creation. It is well known in the commercial approach, focused on shareholder interests and economic efficiency of the company, separation of ownership and control and domination of the board in terms of management. According to Nobel laureate Milton Freedman $^{5}$ "first and only duty of the managers (who are legal representatives of the financial interests of the owners) is to act in a manner that will allow maximizing the financial return on equity." The company must be addressed as the best interests of shareholders, because they bear the residual risk (invested capital and bear the risk of losing it).

\footnotetext{
3 Adolf Berle and Gardiner Means, The Modern Corpoartion and Private Property, 1932.

4 Adolf Berle and Gardiner Means, The Modern Corpoartion and Private Property, second revised edition, 1967.

5 Milton Freedman 1912-2006, American economist, Nobel Prize in Economics in 1976, ranked as the second best economist of the 20th century after John Maynard Kejnes.
} 
The interests of shareholders predominantly affect the strategy of the company (managers agents that meet the requirements of shareholders).

Managers are responsible and should ensure economic efficiency of the company, but are responsible for bad instructions caused damage or destruction of capital to shareholders. Responsibility towards the other stakeholders and protecting their interests derived variable, subordinated to the main objective. It is the postulates that the model is built.

Picture No.1 Revised Berle - Means model

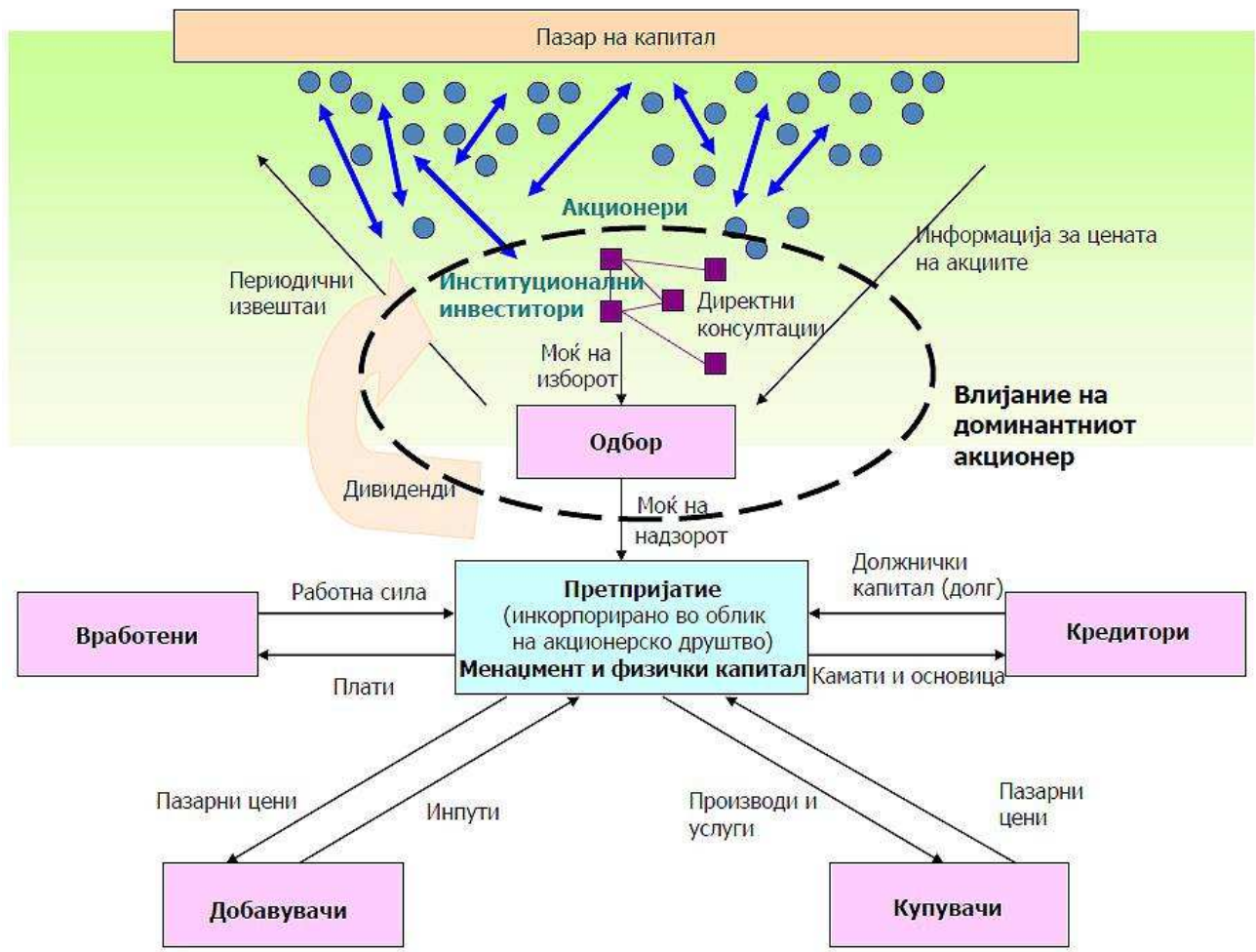

Source: Professor Darko Tipurić, Corporate governance, Faculty of Economics, 2013.

\section{Stakeholder model}

"Profit and its maximization values are irrelevant. Profit is not the explanation, cause or ratio between business and business decisions, it is primarily a test of their validity. "Peter Drucker

The company is an economic entity as much as it is a social entity. It creates its value by taking several different social roles and tasks. The company is not solely an instrument of shareholders, but to all those with some resources, in a way contributing to its normal functioning and because shareholders are not entitled to their interests to put before the interests of other stakeholders. Supporters of this model say that the commercial model is unrealistic and legally unacceptable.

The modern company of the $21 \mathrm{st}$ century need to build and develop a model of corporate governance that recognizes and respects the importance of the interests of all constituents and that would establish targets that satisfy all the key interest groups. 
Picture No. 2 Stakeholder model

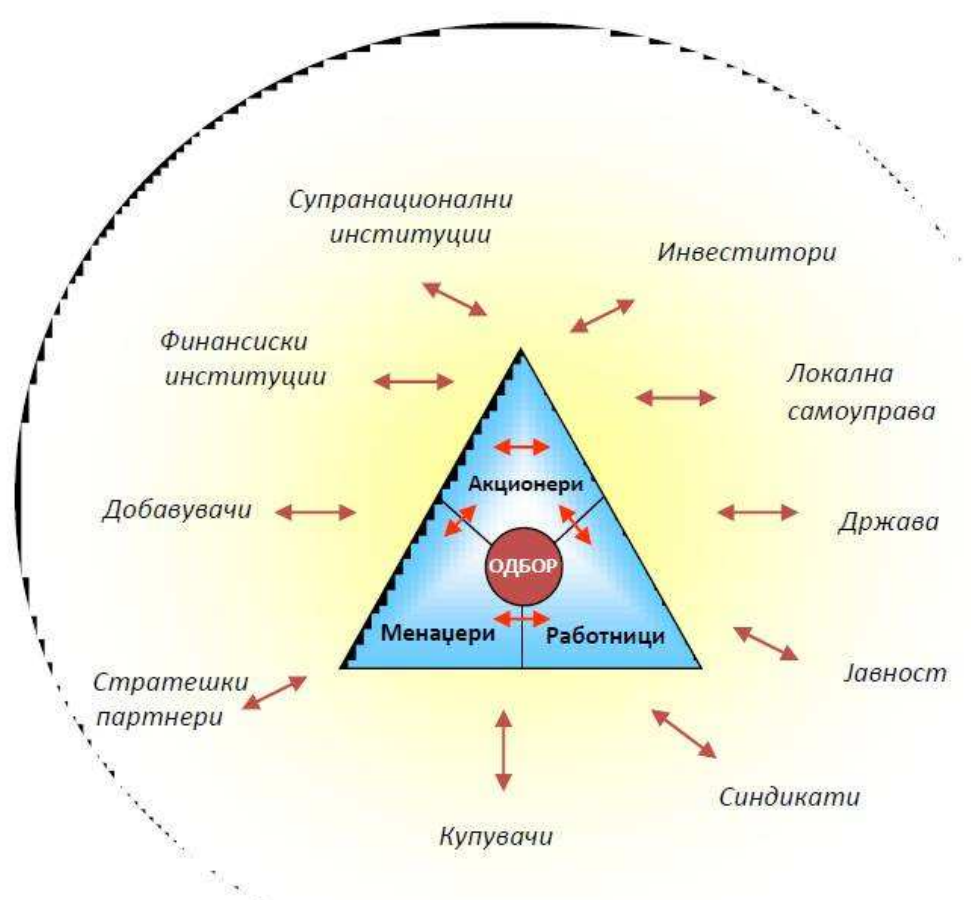

Source: Professor Darko Tipurić, Corporate governance, Faculty of Economics, 2013.

Setted international standards that provide the framework for good corporate governance, a blend of these two models of corporate governance. Development, promotion and strengthening of corporate governance led to the creation of a model with elements of Berle - Means and Stakeholder model, which assumes that a model of a modern company in the 21st century that meets the needs of the process of globalization. Companies that are characterized by good corporate governance look after the interests of all stakeholders, focus and develop corporate social responsibility which embodies the company as a social entity, but on the other hand we can not say that the interests of shareholders are equal to the other stakeholders. Their role, rights, obligations and responsibilities are clearly defined and determine what place they have in the company.

The company creates value if: produce goods or services that users are worth more than the price paid; if it provides an opportunity for managers and employees to be more productive at work here than elsewhere; if it ensures greater or long-term profit to its shareholders; if it creates greater benefit to the environment in terms of the costs of its action.

The modern company of the $21 \mathrm{st}$ century tends to satisfy the demands of all stakeholders while maximizing the ability to create wealth. 
Picture 3 Determination of the company's goals in a system with good corporate governance

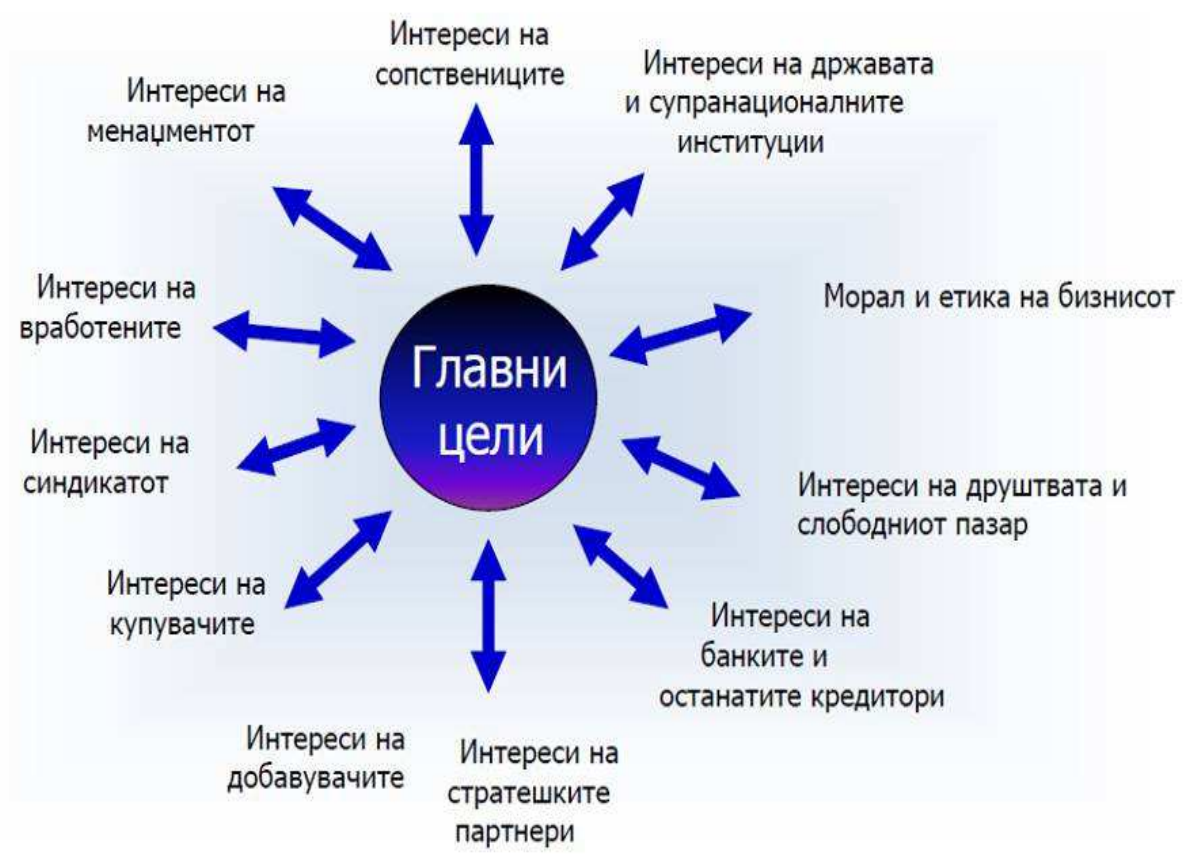

Every modern company that wants to be competitive in the global market, which tends to long-term economic growth and development is faced with the challenge of creating wealth in a responsible way for all key stakeholders. To be ethical, responsible and profitable it is imperative for every company. As social antibodies were with pluralistic interests and goals the company must harmonize different interests in terms of easier realization of the economic order.

\section{Conclusion}

The introduction of corporate governance is the standardization of processes, procedures and behavior in companies, which are based on transparency, accountability, responsibility and control daily operations and reporting on the state of the company. The aim is to increase confidence, reduce risk and create certainty for investors. It helps to improve the performance of the company and increase its value, making it more competitive and attractive market for investment. Companies with good corporate governance systems that build upon the postulates of the modern company of the 21 st century not only make decisions in order to achieve economic interest, but decisions will not harm the interests of other stakeholders.

An effective system of corporate governance requires a high degree of transparency and disclosure, as demonstrated through continuous reporting on the situation of the company. The world economic crisis and the stability of the financial system are introducing quite reforms in this segment. Today I have set international standards of transparency, 
which specifically take into account the financial institutions and companies listed on the exchange.

It greatly increased the safety of investors, they have insight, where investing, what is the degree of risk and what they can expect.

The process of globalization trends and to build infrastructure in a fair, ethical and transparent market relations, imposed process of convergence of legal regulations in the area of corporate governance. The aim is to introduce corporate language to understand all market participants. Each country has its own freedom regulation should be adopted in accordance with the corporate setting, but it should also be based on international standards and principles. This leads to the acceptance of a common framework of good corporate governance globally.

\section{Bibliography}

[1] Adolf Berle and Gardiner Means, The Modern Corpoartion and Private Property, 1932.

[2] Adolf Berle and Gardiner Means, The Modern Corpoartion and Private Property, second revised edition, 1967

[3] Ph.D. Darko Tipurić, Corporate governance, Faculty of Economics, 2013. 